\title{
JAROSŁAW RUBACHA
}

\section{RUCH LUDOWY W BUŁGARII W LATACH 1914-1944}

Dynamiczny rozwój bułgarskiego ruchu ludowego w Bułgarii, trwający od lat 90. XIX w. w dobie wojen bałkańskich, uległ zahamowaniu, a wydarzenia wojenne rozbiły organizacyjną jedność Bułgarskiego Ludowego Związku Chłopskiego (BLZCh). Wielu członków ugrupowania przywdziało mundury, a cenzura uniemożliwiała publikowanie „Zemedełsko zname”. Groziło to zupełnym paraliżem działalności i motywowało działaczy do podejmowania akcji w celu zmiany tej niebezpiecznej sytuacji. Aby zapobiec zupełnemu rozkładowi organizacji, liderzy ludowi odwiedzali $d r u z ̇ b i^{1}$ i zachęcali chłopów do odbudowy przynajmniej szkieletów wiejskich stowarzyszeń. Ale szerzej zakrojona akcja stała się możliwa dopiero po zakończeniu działań wojennych, kiedy zniesiono cenzurę i wznowiono wydawanie organu prasowego. Już $\mathrm{w}$ pierwszych numerach zachęcano czytelników do przesyłania składek, które zamierzano przeznaczyć przede wszystkim na odbudowę struktur Związku oraz informowano o wykluczeniu z szeregów partyjnych Dimityra Straszimirowa, któremu zarzucano skrajnie prowojenne nastawienie w okresie wcześniejszym. Potępienie postawy tego lidera wpisywało się w ogólną falę krytyki, jaka przetaczała się w tym czasie przez Bułgarię i kierowała się przeciw carowi oraz związanym z nim kręgom politycznym, których obarczano winą za tragedię narodową ${ }^{2}$. $Z$ kolei liberałowie odpowiedzialność za wynikły stan zrzucali na byłych premierów: Iwana Geszowa i Stojana Danewa. Co więcej, stwierdzali, że antywojenna postawa BLZCh przyczyniła się do militarnej klęski Bułgarii w okresie II wojny bałkańskiej.

Zacięte spory i dyskusje wokół tej pierwszej katastrofy narodowej (jak przyjęto ją nazywać w historiografii) trwały kilka miesięcy, ale rzeczywisty stan nastrojów społecznych ukazały wybory do nowego XVI Zgromadzenia Narodowego, które odbyły się 24 listopada 1913 r. Mimo że Dobrudża, jeden z najsilniejszych „chłopskich” okręgów wyborczych, znalazła się w granicach Rumunii, BLZCh otrzymał ponad 100 tys. głosów, co dało mu drugi wynik wyborczy i pozwoliło wprowadzić 48 posłów do Parlamentu³.

${ }^{1}$ Drużba była najmniejszą strukturalną jednostką Związku działającą w terenie.

2 Na ten temat szerzej: K. Kożucharow, Aleksander Stambolijski, Warszawa 1961, s. 22-23.

${ }^{3}$ R. J. Crampton, Bulgaria 1878-1918. A History, New York 1983, s. 429-430. 
Tabela 1. Wyniki wyborów do XVI Zgromadzenia Narodowego

\begin{tabular}{|l|l|l|l|}
\hline Partia & Liczba mandatów & Liczba głosów & \% głosów \\
\hline Koalicja liberalna & 95 & 207,763 & 38,2 \\
\hline BLZCh & 48 & 113,761 & 20,9 \\
\hline „Szerocy" socjaliści & 17 & 55,171 & 10,2 \\
\hline Tesniacy & 18 & 54,217 & 10,0 \\
\hline Demokraci & 15 & 42,971 & 7,9 \\
\hline Narodowcy (Geszowiści) & 5 & 24,344 & 4,5 \\
\hline Radykalni demokraci & 5 & 24,007 & 4,4 \\
\hline Postępowi liberałowie (Danewiści) & 1 & 11,863 & 2,2 \\
\hline Inni & 0 & 9,333 & 1,7 \\
\hline RAZEM & 204 & 543,430 & 100,0 \\
\hline
\end{tabular}

Źródło: J. D. Bell, Peasants in Power. Alexander Stamboliski and the Bulgarian Agrarian National Union, 1899-1923, New Jersey 1977, s. 110.

Jeszcze przed pierwszym posiedzeniem Zgromadzenia, 6 grudnia 1913 r. w Sofii, rozpoczął się XIV Kongres BLZCh, którego obrady zdominowały dwie kwestie - sąd partyjny nad Straszimirowem i trzema innymi członkami partii, którzy złamali antywojenną linię Związku oraz określenie kursu działania deputowanych chłopskich w Zgromadzeniu Narodowym. Straszimirow bronił się, powołując się na tureckie okrucieństwa dokonane na Bułgarach macedońskich. Zbrodnie te, jego zdaniem, w pełni usprawiedliwiały wojnę o wyzwolenie Macedonii. Na koniec stwierdził, że jeśli jego poglądy na wojnę różniły się od opinii większości członków Związku, to jednak jako wolny człowiek i obywatel miał prawo do wyrażania swego zdania. Decyzja delegatów nie była jednak dla niego pomyślna. Większość, pod wpływem Aleksandyra Stambolijskiego i Dimityra M. Dimitrowa, opowiedziała się za dożywotnim pozbawieniem go członkostwa w BLZCh${ }^{4}$.

Druga kwestia, którą zajął się Kongres, była o wiele istotniejsza. W wyborach do XVI Zgromadzenia Narodowego żadna partia nie uzyskała odpowiedniej większości, aby samodzielnie sformować rząd. Tym samym na bułgarskiej scenie politycznej rozpoczęły się konsultacje na temat stworzenia koalicji. W ich trakcie pojawiła się - przedstawiona przez lidera Partii Demokratycznej Aleksandyra Malinowa - inicjatywa powołania antyliberalnego bloku złożonego z demokratów, ludowców, radykalnych demokratów i socjalistów, który stanowić miał zaplecze dla koalicyjnego gabinetu. Pomysł ten spotkał się jednak z niejednolitą oceną działaczy BLZCh, a jej krytykiem stał się Stambolijski, który zachęcał zgromadzonych na Kongresie do odrzucenia tej propozycji. Twierdził on bowiem, że jakkolwiek ludowcy byliby największą stroną koalicji, z pewnością musieliby się zgodzić na

\footnotetext{
4 Z. Hemmerling, Ruch ludowy w Polsce, Bułgarii i Czechosłowacji 1883-1930, Warszawa 1987, s. 75.
} 
różne kompromisy, co - w jego ocenie - prowadziłoby do zdrady ideałów programowych partii i włączenia się Związku do walki o władzę, charakterystyczną dla partii politycznych. Tym samym stanął on na stanowisku, że Związek może rządzić Bułgarią tylko wówczas, gdy będzie miał większość w Zgromadzeniu. Ostatecznie Kongres przychylił się do opinii Stambolijskiego i zabronił swoim deputowanym wchodzenia do jakichkolwiek koalicji.

Działalność nowo wybranego Parlamentu trwała jednak zaledwie 12 dni, 13 grudnia 1913 r. został on rozwiązany, a nowe wybory rozpisano na 23 lutego 1914 r. Do tego czasu skład okręgów wyborczych został uzupełniony o dwa nowe rejony: Giurmjurdżina w Tracji Zachodniej i Strumnica w Macedonii Pirińskiej. Dzięki temu Zgromadzenie Narodowe powiększyło się o 41 mandatów, które w większości przypadły w udziale rządzącym liberałom. Równocześnie jednak w trakcie wyborów dał się zaobserwować dalszy wzrost popularności BLZCh. Mimo że w nowych okręgach Związek nie posiadał ani $d r u \dot{z} b i$, ani nie wystawił żadnego kandydata, to w całej Bułgarii oddano na niego niemal 150 tys. głosów, co pozwoliło mu wprowadzić do Zgromadzenia o trzech posłów więcej niż przy okazji poprzednich wyborów.

Taki stan rzeczy umacniał pozycję BLZCh jako lidera opozycji i pozwalał mu kontynuować znaną z okresu wcześniejszego taktykę polityczną. Posłowie chłopscy nadal ignorowali tronowe mowy Ferdynanda, a poza Parlamentem liderzy Związku stale oskarżali cara i sprzyjające mu partie polityczne za katastrofę wojen bałkańskich ${ }^{5}$. Wyrazem opozycyjnej działalności coraz częściej stawały się demonstracje organizowane i kierowane przez ludowców. Do najgłośniejszych należał protest z 30 czerwca 1914 r. - w rocznicę ataku sił bułgarskich na Greków i Serbów w Macedonii - pod pomnikiem Aleksandra II. W jego trakcie Stambolijski sugerował, że monument ten mógłby stać się szubienicą dla cara Ferdynanda. Wystąpienie to zostało wykorzystane przez rząd do wywołania skandalu politycznego, a Stambolijskiemu zagrożono procesem o znieważenie majestatu monarchy.

Ten incydent został jednak wkrótce zepchnięty na dalszy plan za sprawą zabójstwa następcy tronu Austro-Wegier, arcyksięcia Franciszka Ferdynanda i wybuchu I wojny światowej. Odnosząc się do nowej sytuacji, w jakiej znalazła się Europa, już 5 sierpnia 1914 r. Stambolijski przedstawił linię polityczną BLZCh na najbliższą przyszłość. W programie tym stwierdzał, że w związku z nieprzewidywalnym obrotem wydarzeń wojennych, Bułgaria, mocno jeszcze osłabiona po klęskach z roku 1913, powinna pozostać neutralna, a Związek powinien uczynić wszystko, co w jego mocy, by ocalić pokój. Dlatego też zgodnie z jego instrukcjami chłopskie koło parlamentarne spotykało się codziennie i dyskutowało zarówno o sytuacji na frontach, jak i o nastrojach politycznych w kraju oraz wysyłało swoich reprezentantów na spotkania partii opozycyjnych i deputowanych rządowych, a pod koniec sierpnia wraz z demokratami, socjaldemokratami, narodowcami, radykalnymi demokratami i postępowymi liberałami wydało wspólną odezwę wzywającą rząd do zachowania neutralności.

5 Zob. G. C. Logio, Bulgaria. Problems and Politics, London 1919, s. 67-68. 
Generalnie nastroje społeczne były jednak inne. Większość społeczeństwa opowiadała się za przystąpieniem Bułgarii do wojny, w czym widziano szansę na realizację terytorialnych postanowień traktatu bułgarsko-serbskiego z $1912 \mathrm{r}$. i podział Macedonii odpowiadający aspiracjom Bułgarów. W reakcji na te głosy Stambolijski stwierdził, że ani on, ani BLZCh nie są przeciwni odzyskaniu Macedonii czy Dobrudży, jeśli tylko odbędzie się to na pokojowych warunkach. Natomiast ideę zaangażowania się Bułgarii w wojnę poddał zdecydowanej krytyce. Głównym argumentem zachowania neutralności był - jego zdaniem - fakt tradycyjnego podziału bułgarskiej sceny politycznej na obozy: germanofilski i rusofilski. Tym samym przystąpienie Bułgarii do wojny po którejkolwiek ze stron konfliktu groziło destabilizacją sytuacji w kraju i prowadzić mogło do wewnętrznych sporów.

Tymczasem powołany jeszcze w 1913 r. rząd z Wasiłem Radosławowem na czele, który po ciężkich bojach politycznych uzyskał większościowe zaplecze parlamentarne, rozpoczął przygotowania wojenne ${ }^{6}$. Jakkolwiek Bułgaria pozostawała neutralną, to jednak od lipca 1914 do września 1915 r. prowadził on rokowaniami zarówno z państwami centralnymi, jak i z Ententą. Wynik owych negocjacji był jednak niemal od początku przesądzony. Trójporozumienie nie było w stanie zaproponować Bułgarii nic poza nabytkami terytorialnymi w Tracji i mglistymi obietnicami korekt granic w Macedonii. Tymczasem te właśnie ziemie stanowiły obiekt szczególnego zainteresowania Bułgarów. Tym samym sympatie rządu sofijskiego zaczęly przechylać się na stronę państw centralnych, które zobowiązywały się do przekazania Bułgarii nie tylko całej Macedonii, lecz także części wschodniej Serbii ${ }^{7}$. Kolejnym ważnym czynnikiem była także ogólna sytuacja na frontach I wojny światowej. Po przejściowych sukcesach Ententy w 1914 r., inicjatywę przejęły państwa centralne, a odnoszone przez nie zwycięstwa pozwalały przypuszczać, że konflikt zakończy się wkrótce ich zwycięstwem. Wszystkie te czynniki, w połączeniu z germanofilskim nastawieniem gabinetu Radosławowa, zadecydowały ostatecznie o przyłączeniu się Bułgarii do koalicji mocarstw centralnych. 6 września 1915 r. podpisano tajny traktat z Niemcami i Austro-Węgrami, uzupełniony później konwencją wojskową ${ }^{8}$ Poza tym Bułgaria zatwierdziła także traktat $\mathrm{z}$ Turcją, na mocy którego korekcie uległa granica między oboma państwami w okolicach Swilengradu i Adrianopola?

Podpisanie układów sojuszniczych spotkało się z różnym przyjęciem w Bułgarii, a zdecydowanie wystąpili przeciw nim zwolennicy zachowania neutralności ze

${ }^{6}$ Na temat działalności swojego rządu pisze obszernie: W. Radoslawoff, Bulgarien und die Weltkreise, Berlin 1923, s. 83-131.

7 Szerzej na temat negocjacji prowadzonych przez mocarstwa z Bułgarią: G. C. Logio, op. cit., s. 12-17, 120-133 i n.; zob. także: A. T. Christoff, The Truth about Bulgaria, b.m.w., s. 17-24 oraz W. Radoslawoff, op. cit., s. 154, 167-168, 186-193.

8 Teksty obu dokumentów w: J. Rubacha, A. Malinowski, A. Giza, Historia Bułgarii 1870-1915. Materiały źródłowe z komentarzami, t. I, Warszawa 2006, s. 143-146.

9 Tekst dokumentu: ibidem, s. 153-154; zob. także: R. B. Mowat, Select Treaties and Documents to Illustrate the Develepment of the Modern European States System 1815-1916, Oxford 1916, s. 134. 
Stambolijskim na czele ${ }^{10}$. Protesty jednak nie zmieniły sytuacji, a lidera ludowców aresztowano i osadzono w więzieniu.

W październiku 1915 r., wypowiadając wojnę Serbii, Bułgaria przystąpiła do wojny ${ }^{11}$. Już w pierwszych dniach walk Bułgarzy przecięli linię kolejową łączącą Belgrad z Salonikami, jedyną drogę, przez którą Serbowie otrzymywali sprzęt wojenny i zaopatrzenie, następnie zajęli serbską część Macedonii i starli się z angielsko-francuskimi oddziałami, które zmusili do odwrotu ${ }^{12}$. Ciężar walk przeniesiony został do greckiej części Macedonii, gdzie utworzono tzw. Front Salonicki. Początkowe sukcesy wojenne spowodowały wybuch narodowego entuzjazmu. Rząd bez większych problemów przeforsowywał nowe uchwały o kredytach wojennych dla armii, które poparli nawet, pozbawieni przywódcy, członkowie BLZCh.

Przyłączenie się Bułgarii do wojny rozpoczęło jednak kolejny trudny okres w dziejach Związku. Po raz kolejny zawieszono wydawanie „Zemedełsko zname” i praktycznie zaprzestano aktywności politycznej. Lokalne drużbi, pozbawione centralnego kierownictwa, w większej części kraju przerwały swą działalność, a BLZCh na pewien czas całkowicie stracił wpływ na bieg wydarzeń.

W 1915 r. naczelne dowództwo państw centralnych było przekonane, że działania wojenne zakończą się w ciągu czterech miesięcy, gdy tylko Bułgarzy opowiedzą się po ich stronie ${ }^{13}$. Kiedy jednak wojna zaczęła się przedłużać i nic nie wskazywało na jej szybkie zakończenie, nastroje w Bułgarii uległy gwałtownej zmianie ${ }^{14}$. Ogromne zaangażowanie siły pociągowej i mężczyzn w działania na froncie sprawiły, że w rolnictwie pracowało coraz mniej osób. To z kolei wpłynęło na znaczne ograniczenie uprawnego areału, a tym samym spowodowało spadek plonów. Również masowy wywóz produktów rolniczych oraz bogactw naturalnych do Niemiec w znaczący sposób przyczynił się do klęski głodu w 1917 r. ${ }^{15}$ i osłabił sympatie społeczeństwa bułgarskiego dla państw centralnych. W rezultacie doszło do radykalizowania się opinii społecznej, której wyrazem były masowe dezercje z armii, bunty w garnizonach i wystąpienia chłopskie przeciw rekwizycjom wojennym.

W drugiej połowie 1917 r. ogólna sytuacja społeczno-gospodarcza w Bułgarii była katastrofalna, co sprawiło, że polityka prowadzona przez rząd Radosławowa podda-

${ }^{10}$ G. C. Logio, op. cit., s. 1, 7-8, 68, na ten temat także: W. Radoslawoff, op. cit., s. 155.

${ }_{11}$ Zob. Ch. J. Vopicka, Secrets of the Balkan, Chicago 1921, s. 63. Manifest o wypowiedzeniu wojny Serbii dostępny w: G. C. Logio, op. cit., s. 152-153 oraz J. Rubacha, A. Malinowski, Historia Bułgarii 1870-1915. Materiały źródłowe z komentarzami, t. III, Warszawa 2009, s. 86-87.

${ }_{12}$ Szerzej na ten temat: G. W. Price, The Story of the Salonica Army, London-New York-Toronto 1918, s. 41-57; zob. także: W. Radoslawoff, op. cit., s. 194-198.

${ }_{13}$ Zob. G. W. Price, op. cit., s. 137-141; na ten temat także: R. Crampton, Bulgaria, s. 451.

${ }^{14}$ W. Radoslawoff, op. cit., s. 207.

${ }^{15}$ Na ten temat szerzej: Z. Hemmerling, op. cit., s. 120-121; zob. także: J. Pajewski, Pierwsza wojna światowa 1914-1918, Warszawa 1991, s. 722 oraz A. Juszkiewicz, W kraju słońca. Wieś bułgarska wczoraj i dziś, Warszawa 1965, s. 97; wszelkie aspekty ekonomicznej sytuacji w Bułgarii omawia szczegółowo: G. C. Logio, op. cit., s. 195-230. 
wana była coraz szerszej krytyce ${ }^{16}$. W jej efekcie, 16 czerwca 1918 r., car Ferdynand odwołał premiera wraz z całym gabinetem, a na czele nowego rządu stanął jeden z przywódców opozycji A. Malinow ${ }^{17}$. Nie zmieniło to jednak sytuacji ani w kontekście wewnętrznym, ani zewnętrznym.

Ostateczne załamanie militarnej pozycji Bułgarii nastąpiło na froncie w Macedonii. 15 sierpnia 1918 r. wojska angielskie, francuskie, serbskie i greckie pod dowództwem generała Louisa Félixa Francheta d'Espereya, wsparte potężnym ostrzałem artyleryjskim, zaatakowały pozycje bułgarskie pod Dobro Pole ${ }^{18}$. Przewaga przeciwników była tak duża, że po krótkiej walce Bułgarzy zmuszeni zostali do odwrotu, a rozgoryczeni klęską, wycofujący się żołnierze 24 września opanowali sztab główny w Kiustendił ${ }^{19}$. W tych okolicznościach Rada Królewska zdecydowała się doprowadzić do jak najszybszego zawieszenia broni. Rozmowy na ten temat podjęła delegacja na czele z ministrem finansów Andrejem Liapczewem, gen. Iwanem Łukowem i Simeonem Radewem. Efektem konsultacji było podpisanie w dniu 29 września w Salonikach kapitulacji i przyjęcie warunków postawionych przez głównodowodzącego wojsk Ententy. Przewidywały one m.in.: ewakuację armii bułgarskiej z okupowanych jeszcze terytoriów serbskich, demobilizację armii, wydanie sprzętu wojennego oraz okupację niektórych punktów strategicznych w Bułgarii ${ }^{20}$.

W tym samym czasie w Bułgarii doszło do gwałtownych wydarzeń politycznych ${ }^{21}$. Wycofujące się z frontu jednostki bułgarskie, pałające żądzą ukarania winnych klęski na frontach I wojny światowej, bardzo szybko ulegały nastrojom rewolucyjnym, co ostatecznie - w końcu września 1918 r. - doprowadziło do wybuchu tzw. powstania żołnierskiego, które objęło swym zasięgiem tereny południowo-zachodniej Bułgarii. Starając się opanować sytuację, car Ferdynand uwolnił osadzonego wcześ-

${ }^{16}$ Szerzej na ten temat: R. Crampton, Bulgaria, s. 460-465.

17 Zob. G. C. Logio, op. cit., s. 2. Zmiana gabinetu związana była z konfliktem między Radosławowem a państwami centralnymi powstałym po zawarciu przez te ostatnie pokoju z Rosją w Brześciu Litewskim. Brak definitywnych rozstrzygnięć w kwestii przynależności północnej Dobrudży był głównym czynnikiem przesądzającym o odwołaniu rządu. $Z$ drugiej strony, przekazanie władzy w ręce polityków związanych $z$ Ententą, w radykalnie odmiennej sytuacji na frontach wojny, miało pozwolić Bułgarii wyjść z konfliktu bez większych strat. Nadzieje te nie zostały spełnione, ponieważ rząd Malinowa pozostał wierny państwom centralnym do końca wojny; ibidem, s. 174-177; kwestię tę relacjonuje także: W. Radoslawoff, op. cit., s. 273-286.

18 Szczegółowy opis działań sił sprzymierzonych przeciw armii bułgarskiej w: H. Collinson Owen, Salonica and After. The Sideshow That Ended the War, London-New York-Toronto 1919, s. 244-266; zob. także: A. Giza, Bułgaria i problem macedoński od początku XVIII wieku do lat trzydziestych XX wieku, Szczecin 2003, s. 229.

19 R. Crampton, Bulgaria, s. 468.

20 Zob. Nacionalno-osvoboditelnoto dviženie na Makedonskite i Trakijskite B"lgari 1878-1944, red. D. Miczewa, t. 4, Sofiâ 2003, s. 10-11; na ten temat także: J. Pajewski, op. cit., s. 725 oraz W. Radoslawoff, op. cit., s. 313 .

${ }^{21}$ Na ten temat szerzej: Ch. Christow, Revolucionnata kriza w B"lgariâ prez 1918-1919, Sofiâ 1957; zob. także: R. J. Crampton, Eastern Europe in Twentieth Century and after, London 1997, s. 119. 
niej w areszcie A. Stambolijskiego w nadziei, że podejmie się on misji skłonienia żołnierzy do złożenia broni i zaprzestania rebeliii ${ }^{22}$. Ten jednak zamiast rozpocząć negocjacje z powstańcami, sam stanął na ich czele. Wkrótce otrzymał on jednak depeszę od posła z ramienia BLZCh - Rajko Daskałowa ${ }^{23}$, z której dowiedział się, że z Radomiru wyruszyły w kierunku Sofii oddziały powstańcze liczące 8 tys. żołnierzy. Równocześnie Daskałow donosił o proklamowaniu republiki ${ }^{24}$ pod egidą Stambolijskiego oraz wystosowaniu do rządu w Sofii ultimatum, w którym domagano się jego dymisji. Taki stan rzeczy zaskoczył Stambolijskiego, który będąc świadomym rządowych przygotowań do zbrojnej rozprawy z powstańcami, odciął się od inicjatywy Daskałowa i przedstawiał się jedynie jako lider BLZCh ${ }^{25}$. Jego decyzja okazała się właściwa. 29 września z Sofii wyruszyły oddziały wierne rządowi, wsparte jednostkami niemieckiej 217 Dywizji Piechoty, które kilka dni później rozbiły wojska powstańcze i stłumiły rebelię.

Upadek powstania żołnierskiego nie wpłynął jednak na złagodzenie rewolucyjnych nastrojów w społeczeństwie. W obawie przed kolejną rewoltą, 18 października, w skład rządu Malinowa powołano nowych koalicjantów w postaci przedstawicieli „szerokich” socjalistów ${ }^{26}$ i BLZCh. Gabinet ten nie przetrwał jednak długo, a główną przyczyną jego upadku była powszechna krytyka z powodu kompromisowej postawy w kwestii przynależności południowej Dobrudży oraz niechęci do realizacji obietnicy zwolnienia więźniów politycznych, którą rząd złożył w czasie rozmów ze Stambolijskim jeszcze 27 września. W listopadzie 1918 r. misję sformowania nowego gabinetu otrzymał Teodor Teodorow, lider partii narodniackiej ${ }^{27}$.

Podejmowane przez Teodorowa próby zjednoczenia narodu bułgarskiego nie dały jednak pozytywnych rezultatów. Stały spadek poziomu stopy życiowej, a zwłaszcza srogie postanowienia traktatu z Neuilly-sur-Seine ${ }^{28}$ pogłębiały rozdźwięk w społeczeństwie. Uwidoczniło się to w kolejnych wyborach parlamentarnych w sierpniu 1919 r., które przyniosły zwycięstwo ludowcom i Bułgarskiej Partii Komunistycznej $(\mathrm{BPK})^{29}$.

${ }^{22}$ Zob. Z. Hemmerling, op. cit., s. 122-123.

${ }^{23}$ Zob. D. Petrowa, D-r Rajko Daskalov. Politik i d"ržavnik reformator, Stara Zagora 1995, s. 3-7.

24 Tzw. Republika Radomirska.

${ }^{25}$ R. Crampton, Bulgaria, s. 469.

${ }^{26}$ W 1903 r. Bułgarska Robotnicza Partia Socjaldemokratyczna (BRSDP) obejmująca dotąd dwa skrzydła bułgarskiego ruchu socjalistycznego: lewicowe, tzw. „partyjnych”, i prawicowe, tzw. „związkowców”, rozpadła się na dwie partie socjaldemokratyczne. Prawica utworzyła BRSDP, tzw. „szerokich socjalistów”, a lewica BRSDP, tzw. „tesniaków”, czyli zwolenników wąskiego pojmowania marksizmu.

27 Zob. M. Kumanow, Leviât politiczeski spekt" $r$ w B"lgarija (1918-1934), http://bgsocialism.eu/kumanov.pdf (14.02.2009). W rządzie tym z ramienia BLZCh zasiedli: C. Bakałow, D. Dragiew i A. Stambolijski; na ten temat szerzej: I. Rankoff, Bauerndemokratie in Bulgarien, w: Europäische Bauernparteien im 20. Jahrhundert, hrsg. von H. Gollwitzer, Stuttgart / New York: Fischer 1977, s. 476.

${ }_{28}$ Tekst traktatu dostępny m.in. w: Treatry of peace between the Allied and Associated Powers and Bulgaria and protocol. Signed at Neuilly-Sur-Seine. November 27, 1919, Ottawa 1920.

29 R. J. Crampton, A Concise History of Bulgaria, Cambridge 2003, s. 149. 
Tabela 2. Wyniki wyborów do XVIII Zgromadzenia Narodowego

\begin{tabular}{|l|l|l|l|}
\hline Partia & Liczba posłów & Liczba głosów & \% głosów \\
\hline BLZCh & 85 & 180,648 & 28 \\
\hline BPK & 47 & 118,671 & 18 \\
\hline${ }_{\text {,Szerocy” socjaliści }}$ Demokraci & 36 & 82,826 & 13 \\
\hline Narodowcy & 28 & 65,267 & 10 \\
\hline Postępowi liberałowie & 19 & 54,556 & 8 \\
\hline Liberałowie & 8 & 52,722 & 8 \\
\hline Radykalni demokraci & 2 & 42,024 & 6 \\
\hline Inni & 8 & 33,343 & 5 \\
\hline RAZEM & 3 & 26,258 & 4 \\
\hline
\end{tabular}

Źródło: J. D. Bell, Peasants in Power, s. 143.

19 września 1919 r. Stambolijski otrzymał od nowego cara Borysa III $^{30}$ mandat do utworzenia nowego rządu. Ludowcy nie mieli jednak wystarczającej większości w Parlamencie i zmuszeni byli do sformowania koalicji. Stambolijski zaproponował więc uczestnictwo w sprawowaniu rządów BPK, lecz ta odrzuciła ofertę, podobnie jak socjaliści ${ }^{31}$. Niemożność znalezienia koalicjanta po lewej stronie sceny politycznej zmusiła BLZCh do zwrócenia się w kierunku partii prawicowych, co ostatecznie umożliwiło sformowanie gabinetu, w którego skład weszli oprócz ludowców także przedstawiciele narodniaków i postępowych liberałów. Zdecydowaną przewagę posiadali w nim jednak ludowcy, którzy objęli siedem na dziesięć ministerstw: premier A. Stambolijski - Ministerstwo Wojny i Ministerstwo Spraw Publicznych, Rajko Daskałow - Ministerstwo Rolnictwa, Canko Cerkowski - Ministerstwo Edukacji, Aleksandyr Dimitrow - Ministerstwo Spraw Wewnętrznych i Marco Turłakow - Ministerstwo Kolei, Poczty i Telegrafu oraz Ministerstwo Sprawiedliwości.

Pierwszoplanowym zadaniem dla nowego rządu było ustabilizowanie sytuacji wewnętrznej kraju, a jednym $\mathrm{z}$ elementów podjętych w tym zakresie działań było aresztowanie wszystkich członków gabinetu W. Radosławowa, czego domagały się szerokie kręgi społeczne ${ }^{32}$. Równocześnie zatrzymano także tych byłych deputowanych, działaczy rządowych i dziennikarzy, którzy popierali udział Bułgarii w wojnie i których uznawano za odpowiedzialnych za spowodowanie katastrofy narodowej w $1918 \mathrm{r}$. Restrykcje nie ominęły także członków Wewnętrznej Macedońskiej Organizacji Rewolucyjnej (WMOR). Kolejnym etapem miał być program reform, który w postaci ustaw został przyjęty przez Zgromadzenie Narodowe w listopadzie i grudniu $1919 \mathrm{r}$. $1918 \mathrm{r}$.

${ }^{30}$ Borys III objął rządy w Bułgarii po abdykacji swojego ojca Ferdynanda I w dniu 4 października

${ }^{31}$ Na ten temat szerzej: W. Balcerak, Powstanie państw narodowych w Europie Środkowo-Wschodniej, Warszawa 1974, s. 433; zob. także: R. J. Crampton, Eastern Europe, s. 120.

32 Plan działań rządu prezentuje: Z. Hemmerling, op. cit., s. 302-303. 
W jego ramach uchwalono m.in. ustawy o wolności zgromadzeń, handlu artykułami zbożowymi i żywnością oraz opodatkowaniu kapitałów zdobytych podczas wojny i złagodzeniu potrzeb mieszkaniowych. Program ten spotkał się jednak z nieprzychylnym przyjęciem sił prawicowych, a wręcz wrogo odnieśli się do niego komuniści. Z ich inicjatywy organizowane były antyrządowe manifestacje, a przez kraj przetoczyła się fala strajków. Odpowiedzią na nie były masowe zwolnienia urzędników państwowych i samorządowych, którzy brali udział w protestach. Równocześnie zaostrzono cenzurę, a kolejne demonstracje i strajki tłumiono przy użyciu wojska. Te działania jeszcze bardziej zaogniły sytuację, a kiedy rząd zaostrzył politykę względem protestujących, komuniści proklamowali 28 grudnia strajk generalny, który objął transport i łączność, niemal zupełnie paraliżując życie gospodarcze w kraju.

Stambolijski był przekonany, że strajk ma podłoże polityczne i jakkolwiek zdawał sobie sprawę z ciężkiego losu robotników, zdeterminowany był nie iść na żądne ustępstwa. 31 grudnia transport został zmilitaryzowany, a zakłady przemysłowe obsadziło wojsko. Równocześnie ogłoszono mobilizację robotników, a tych, którzy odmówili, eksmitowano z domów, pozbawiano kartek na żywność i zastraszano. Aresztowano także kilku komunistycznych liderów, a resztę zmuszono do zejścia do podziemia. W tej sytuacji BPK ogłosiła zakończenie strajku na 5 stycznia 1920 r., ale dopiero 19 lutego rządowi udało się zlikwidować ostatnie jego ośrodki.

Wraz z formalnym zakończeniem strajku Stambolijski wystąpił do Borysa III z wnioskiem o rozwiązanie Zgromadzenia Narodowego. Car przychylił się do tego i wyznaczył nowe wybory na 28 marca. Tym razem sukces ludowców był ogromny i tylko pięciu mandatów zabrakło BLZCh do uzyskania bezwzględnej większości w Zgromadzeniu Narodowym.

Tabela 3. Wyniki wyborów do XIX Zgromadzenia Narodowego

\begin{tabular}{|l|l|l|l|}
\hline Partia & Liczba mandatów & Liczba głosów & \% głosów \\
\hline BLZCh & 110 & 349,212 & 38,2 \\
\hline BPK & 51 & 184,616 & 20,2 \\
\hline${ }_{\text {,Szerocy" socjaliści }}$ & 7 & 55,542 & 6,1 \\
\hline Demokraci & 23 & 91,177 & 10,0 \\
\hline Narodowcy & 15 & 61,647 & 6,7 \\
\hline Postępowi liberałowie & 9 & 46,930 & 5,1 \\
\hline Koalicje liberalno-narodowe & 6 & 39,573 & 4,2 \\
\hline Radykalni demokraci & 8 & 41,930 & 4,6 \\
\hline Koalicja liberałów i demokratów & 0 & 35,522 & 3,9 \\
\hline Inni & 0 & 9,095 & 1,0 \\
\hline RAZEM & 229 & 915,172 & 100,0 \\
\hline
\end{tabular}

Źródło: J. D. Bell, Peasants in Power, s. 152. 
Zamiast wchodzić w koalicję z innymi partiami, Stambolijski przeforsował, pod pozorem naruszenia zasad ordynacji wyborczej, unieważnienie mandatów 13 deputowanym, w tym 9 komunistom, 3 demokratom i 1 postępowym liberałom. W ten sposób uzyskał nieznaczną większość (4 głosami) w Zgromadzeniu ${ }^{33} .20$ maja $1920 \mathrm{r}$. sformowano nowy gabinet, którego skład przedstawiał się następująco: Aleksandyr Stambolijski - premier, minister spraw zagranicznych i minister wojny, Aleksandyr Dimitrow - minister spraw wewnętrznych, Canko Cerkowski - minister spraw publicznych, Marco Turłakow - minister finansów, Rajko Daskałow - minister handlu, Aleksandyr Radołow - minister sprawiedliwości, Stojan Omarczewski - minister edukacji, Aleksandyr Obbow - minister rolnictwa i Nediałko Atanasow - minister kolei, poczty i telegrafu i ludowcy rozpoczęli samodzielne rządy.

Rządy chłopskie przypadły na trudny okres w historii Bułgarii. Powojenny kryzys nadal dawał się we znaki całemu społeczeństwu ${ }^{34}$. Dlatego też rząd Stambolijskiego robił wszystko, co było w jego mocy, by poprawić sytuację gospodarczą $\mathrm{kraju}^{35} \mathrm{i}$ już na początku zainicjował wiele reform ekonomicznych i społecznych, $\mathrm{z}$ których największe znaczenie miała reforma rolna ${ }^{36}$. W założeniu miała ona przebiegać dwuetapowo. Pierwszym krokiem miało być stworzenie państwowego funduszu ziemi z parcelacji latyfundiów i dużych gospodarstw rolnych, których areał przekraczał 30 ha ziemi, 20 ha lasów i pastwisk, a na obszarach górskich - 50 ha, a kolejnym - przekazanie ziemi bezrolnym i małorolnym chłopom. Reforma ta, jakkolwiek stanowiła poważny krok na drodze do demokratyzacji stosunków na wsi, nie spełniła pokładanych w niej nadziei. Z jednej strony, w Bułgarii nie było większej liczby majątków, które można było poddać parcelacji, a w związku z tym zapas ziemi zgromadzony w funduszu był stosunkowo niewielki, a z drugiej strony, jej rozdział przebiegał bardzo wolno. Dynamicznie rozgrywające się na bułgarskiej scenie politycznej wydarzenia oraz brak wykształconej kadry urzędniczej w szeregach BLZCh ${ }^{37}$ sprawiły, że do 9 czerwca 1923 r., czyli do chwili upadku gabinetu Stambolijskiego, na prawie 80 tys. uprawnionych i zarejestrowanych chłopów oczekujących na ziemię otrzymało ją zaledwie ok. $25 \%{ }^{38}$.

${ }^{33}$ R. J. Crampton, A Concise, s. 151; zob. także: J. R. Lampe, The Bulgarian Economy in Twentieth Century, New York 1987, s. 49-50.

${ }^{34} \mathrm{Na}$ temat stanu bułgarskiej gospodarki w okresie powojennym zob. J. R. Lampe, op. cit., s. $52-56$.

${ }_{35}$ Poselstwo polskie w Sofii tak oceniło rządy chłopskie: „Rządzący w Bułgarii od pół roku chłopski rząd zemedełców dowiódł, że potrafi zwrócić krajowi spokój i dobrobyt. Pomimo olbrzymich strat materialnych i terytorialnych oraz utraty dostępu do morza, kraj nie cierpi niedostatku”. Z. Hemmerling, op. cit., s. 308.

${ }^{36} \mathrm{Na}$ ten temat szerzej: I. Rankoff, op. cit., s. 483-484 oraz J. R. Lampe, op. cit., s. 57. Na temat pozostałych reform przeprowadzonych przez rząd A. Stambolijskiego zob. Z. Hemmerling, op. cit., s. 309-313 oraz J. D. Bell, Peasants in Power. Alexander Stamboliski and the Bulgarian Agrarian National Union, 1899-1923, New Jersey 1977, s. 159-183.

37 I. Rankoff, op. cit., s. 482.

38 Por. R. J. Crampton, Eastern Europe, s. 121. 
Równocześnie ludowcy podjęli działania w innych dziedzinach ${ }^{39}$. Widoczne i znaczące zmiany BLZCh wprowadził w polityce zagranicznej. Stambolijski zdawał sobie sprawę, że kontynuowanie dotychczasowej polityki zagranicznej nie może przynieść poprawy trudnej sytuacji Bułgarii na arenie międzynarodowej. Odrzucając tradycyjny bułgarski nacjonalizm i akceptując powojenne postanowienia, dążył on do stworzenia możliwie dobrych stosunków z sąsiednimi państwami i uniezależnienia kraju od obcych wpływów. Równocześnie, zdając sobie sprawę ze wzrostu politycznego znaczenia ruchu ludowego w Europie, podjął działania na rzecz skonsolidowania działań wszystkich partii i organizacji chłopskich, co mogłoby ułatwić Bułgarii wyjście $\mathrm{z}$ międzynarodowej izolacji ${ }^{40}$. Te ambitne plany Stambolijskiego wymagały jednak niezwykle sprzyjających okoliczności. Po pierwsze, państwa sąsiadujące z Bułgarią musiałyby właściwie odczytać jego intencje, a po drugie, zainteresowanie bułgarskimi inicjatywami musiałyby wyrazić mocarstwa Ententy ${ }^{41}$.

Tymczasem Stambolijski nie miał wielkiego doświadczenia dyplomatycznego, a pierwsze nauki na niwie polityki zagranicznej pobierał dopiero w lipcu 1919 r., kiedy jako członek rządu T. Teodorowa został delegatem na konferencję pokojową w Paryżu, jego niezwykły dynamizm i aktywnośćc ${ }^{2}$ przynosiły relatywnie dobre rezultaty. Jakkolwiek Bułgarom nie udało się złagodzić warunków traktatu z Neuilly-sur-Seine ${ }^{43}$, kraj powoli zaczął być dostrzegany na arenie międzynarodowej, a w grudniu 1920 r. Bułgaria została przyjęta do Ligi Narodów. Stopniowej poprawie ulegały także stosunki Sofii z Francją i Jugosławią. Niewątpliwy wpływ na taki stan rzeczy miały częste zapewnienia Stambolijskiego o pokojowej i antyrewizjonistycznej polityce jego gabinetu. Równocześnie jednak deklaracje te, których wynikiem był m.in. negatywny stosunek Bułgarii do interwencji przeciw Rosji Radzieckiej i zwalczanie działalności WMOR, przysparzały mu tyle samo przyjaciół, co przeciwników. Ci ostatni na arenie międzynarodowej zarzucali rządowi Stambolijskiego sympatię dla bolszewizmu, w kraju natomiast - zdradę narodowych ideałów.

W miarę upływu czasu opozycja wewnętrzna zaczęła przybierać na sile, a największe niebezpieczeństwo groziło rządowi ludowców ze strony korpusu oficerskiego. Ograniczenia w liczebności armii, narzucone w traktacie pokojowym, spowodowały konieczność zwolnienia ze służby znacznej liczby zawodowych wojskowych ${ }^{44}$. Podobnie jak w innych krajach dotkniętych tego typu ograniczeniami, tworzyli oni różnego rodzaju organizacje kombatanckie, które wkrótce stały się trzonem antyrządowej

${ }^{39}$ Na ten temat szerzej: ibidem oraz D. Kazasow, Burni godini 1918-1944, Sofiâ 1949, s. 81-89.

${ }^{40}$ Por. H. Gollvitzer, Europäische Bauerndemokratie in 20. Jahrhundert, w: Europäische Bauernparteien, s. 48, zob. także: R. J. Crampton, Eastern Europe, s. 121-122.

${ }^{41}$ J. D. Bell, op. cit., s. 185.

${ }^{42} \mathrm{Na}$ temat działań dyplomatycznych A. Stambolijskiego zob. E. Znamierowska-Rakk, Sprawa Tracji Zachodniej w polityce bułgarskiej (1919-1947), Warszawa 1991, s. 99-134 oraz Nacionalno-osvoboditelnoto dviženie, s. 82-83.

${ }^{43}$ Chodziło głównie o obniżenie lub zawieszenie spłaty reparacji wojennych, które rujnowały gospodarkę kraju; na ten temat zob. J. R. Lampe, op. cit., s. 60-62.

${ }_{44}$ Zob. ibidem, s. 44 oraz R. J. Crampton, Eastern Europe, s. 122-123. 
opozycji. Równocześnie narastał ferment w armii czynnej. Kręgi wojskowe nie tylko jawnie demonstrowały swoją niechęć do rządu, lecz także oficjalnie wspierały oddziały zbrojne zdelegalizowanej WMOR, a nieskrywanym aktem nieposłuszeństwa była bierna postawa wojska wobec zajęcia przez czetników tej organizacji miasta Kiustendił na początku grudnia $1922 \mathrm{r}$. Za takim stanowiskiem armii stały tajne organizacje skupiające młodych oficerów, a zwłaszcza powołana do życia jeszcze w 1919 r. Liga Wojskowa z Wasiłem Sławejkowem na czele.

Równocześnie przeciw rządom ludowców zwierała szyki opozycja prawicowa. Partie burżuazyjne, dążąc do odzyskania utraconych wpływów, łączyły się w większe ugrupowania, a na bułgarskiej scenie politycznej pojawiły się także nowe organizacje. Jedną z nich było utworzone wiosną 1922 r. Porozumienie Narodowe, na czele którego stanął Aleksandyr Cankow. Z inicjatywy tego ugrupowania rozpoczęto przygotowania do zamachu stanu, w wyniku którego zamierzano usunąć rząd Stambolijskiego. Jakkolwiek sama akcja nie została ostatecznie przeprowadzona, organizacje prawicowe nie zamierzały rezygnować z prób przejęcia władzy. Latem 1922 r. Porozumienie Narodowe oraz kilka innych partii utworzyły tzw. Blok Konstytucyjny, który na przełomie września i października zaplanował zorganizowanie w kilku miastach Bułgarii antyrządowych demonstracji, co skłoniło BLZCh do działania. Związkowi udało się zmobilizować chłopów do akcji przeciw Blokowi Konstytucyjnemu, natomiast rząd, wykorzystując czasowe zbliżenie ludowców z komunistami, przeprowadził 19 listopada 1922 r. referendum dotyczące oddania pod sąd polityków odpowiedzialnych za klęski Bułgarii w 1913 i 1918 r. Ponieważ znaczna ich część nadal była prominentnymi działaczami partyjnymi, wyeliminowanie ich z życia politycznego mogło w znaczący sposób osłabić prawicową opozycję. Sukces podjętych działań utwierdził Stambolijskiego w przekonaniu, że pozycja rządu jest mocna, a jego jedynym poważnym przeciwnikiem na scenie politycznej jest $\mathrm{BPK}^{45}$.

Równocześnie jednak BLZCh borykał się z poważnymi problemami wewnętrzny$\mathrm{mi}^{46}$. W tym czasie w ugrupowaniu coraz większą popularność zdobywało jego prawe skrzydło z M. Turłakowem na czele, krytycznie nastawione do działań rządu. Mimo szybkiej reakcji Stambolijskiego i usunięcia grupy Turłakowa z szeregów stronnictwa, walki frakcyjne w Związku nie ustały.

Elementem konsolidującym Związek i utrwalającym jego dominującą pozycję na bułgarskiej scenie politycznej miało być spektakularne zwycięstwo w kolejnych wyborach parlamentarnych, które zaplanowano na wiosnę 1923 r. Ponieważ ludowcy zdawali sobie sprawę z wagi wyniku wyborczego, postanowili dobrze się do nich przygotować. Na początku roku dokonano rekonstrukcji rządu, usuwając z niego

45 Por. W. Balcerak, op. cit., s. 445.

${ }^{46}$ Powolny rozpad BLZCh rozpoczął się już w 1919 r., kiedy Dragiew dokonał rozłamu w Związku i założył nowe ugrupowanie - BLZCh „Stara Zagora”. Przyczyną rozłamu była ostra krytyka, jakiej poddał on A. Stambolijskiego i R. Daskałowa za zaangażowanie podczas powstania żołnierskiego. Ugrupowanie Dragiewa często było wykorzystywane do prób rozbicia spoistości BLZCh, ale w związku z nikłym poparciem, jakie miało, w II poł. lat 20. XX w. zeszło na margines życia politycznego. 
polityków o niepewnej orientacji politycznej ${ }^{47}$, wzmocniono propagandę antykomunistyczną oraz przygotowano i przeprowadzono zmianę ordynacji wyborczej. Działania te umożliwiły BLZCh osiągnięcie absolutnej przewagi w Zgromadzeniu Narodowym. Na ludowców oddano ponad 200 tys. głosów, co pozwoliło im wprowadzić do Parlamentu 212 posłów. Tym samym zdeklasowali oni rywali; z ramienia komunistów zasiadło w Zgromadzeniu jedynie 16 deputowanych, partie prawicowe wprowadziły 15 posłów, a skład Parlamentu uzupełniło 2 przedstawicieli „szerokich” socjalistów. Wiosenne wybory dały Stambolijskiemu i jego ugrupowaniu wiele powodów do zadowolenia. Dobre nastroje wzmógł także XVIII kongres BLZCh, który odbył się w maju $1923 \mathrm{r}$. W trakcie jego obrad ponad 300 tys. uczestników zjazdów okręgowych złożyło uroczyste ślubowanie, że dochowa wierności Związkowi i reprezentującemu go rządowi. Wydawało się, że nikt i nic nie jest w stanie obalić rządów ludowców ${ }^{48}$.

Przeciwnicy nie zrezygnowali jednak $\mathrm{z}$ walki, a ich przygotowania do ostatecznego rozprawienia się z ludowcami na drodze zamachu stanu prowadzone były z coraz większym rozmachem, zwłaszcza przez kręgi wojskowe. W maju 1923 r., w czasie gdy Związek świętował zwycięstwo wyborcze, do spiskowców przyłączało się coraz więcej ważniejszych garnizonów wojskowych, a do działań przeciw rządowi dołączył także sam car Borys III ${ }^{49}$. Termin zamachu spiskowcy ustalili na 9 czerwca $1923 \mathrm{r}$.

Jakkolwiek do Stambolijskiego coraz częściej docierały ostrzeżenia o planowanej akcji, były one przez niego lekceważone. Podobną nonszalancją wykazywali się zarówno minister spraw wewnętrznych Christo Stojanow, jak i minister wojny Konstantin Murawiew. Mimo że mieli oni pełną świadomość, że w akcji przeciw rządowi może zostać użyte wojsko, nie podejmowali żadnych kroków w celu wyeliminowania zagrożenia. Równocześnie obaj ministrowie składali premierowi bezpodstawne zapewnienia, że rząd kontroluje sytuację w całym kraju.

8 czerwca o godz. 8:30 przywódcy spiskowców spotkali się w domu gen. Iwana Rusewa. W trakcie narady płk Iwan Wyłkow poinformował zebranych, że do wszystkich prowincji wysłał końcowe rozkazy oraz że jednostki wojskowe czekają w pełnej gotowości. Równocześnie spiskowcy wybrali tymczasowy gabinet rządzący, który miał przejąć władzę w kraju.

Następnego dnia o godz. 3.00 w nocy spiskowcy wyprowadzili na ulice Sofii oddziały wojskowe, do których przyłączyły się grupy WMOR i inni ochotnicy. Błyskawicznie udało im się zająć punkty strategiczne i już o godz. 4.00 całe miasto znalazło się w ich rękach. Wówczas zwrócono się do cara Borysa III, by ten odwołał rząd Stambolijskiego i zaakceptował nowy gabinet $\mathrm{z}$ A. Cankowem na czele ${ }^{50}$.

47 Zob. I. Rankoff, op. cit., s. 482.

${ }^{48}$ Stambolijski mówił nawet, że wynik wyborów zagwarantował BLZCh rządy na najbliższych 40 lat; por. M. Kumanow, op. cit.

${ }^{49} \mathrm{Na}$ ten temat szerzej: N. Christosow, Śladem zaginionych bez wieści. (Przekaz tragicznych dla narodu bułgarskiego wydarzeń w kwietniu 1925), Kraków 1979, s. 28.

${ }^{50}$ Szerzej na ten temat: M. Kumanow, op. cit. 
Zdając sobie sprawę z poparcia, jakim cieszył się Stambolijski, spiskowcy przywiązywali dużą wagę do jego szybkiego aresztowania i „odcięcia” od mas chłopskich. Zadanie to powierzono pułkownikowi Sławejko Wasiłewowi. Z lokalnego garnizonu wysłał on grupe ok. 60 żołnierzy z zadaniem wtargnięcia do wilii premiera w Sławowicy i rozbrojenia jego ochrony. Akcja ta jednak nie zakończyła się sukcesem, a oddział Wasilewa zmuszony został do odwrotu. Początkowo Stambolijski sądził, że napad na jego posiadłość nosi znamiona incydentu terrorystycznego i stoi za nim WMOR. Kiedy jednak uświadomił sobie powagę sytuacji, na podjęcie jakichkolwiek działań było już za późno ${ }^{51}$. Wezwane na pomoc oddziały wojskowe wierne rządowi zostały rozbite pod Pazardżikiem, a premier został aresztowany w wiosce Gołak, niedaleko Ichtimanu. Następnie przewieziono go z powrotem do Sławowicy, gdzie - poddany torturom - zmarł 14 czerwca $1923 \mathrm{r}$. Niewielki skutek dały także próby zmobilizowania chłopów do stawienia oporu spiskowcom. Oddziały chłopskie próbowali organizować m.in. Spas Duparinow w okolicach Płowdiwu, Aleksandyr Obbow koło Plewen oraz Georgi Damianow w rejonie Botewgradu. Niestety formacje te, słabo uzbrojone i wyposażone, szybko ulegały siłom wojskowym. Podobnie kończyły się akcje podejmowane w całej Bułgarii przez lokalne drużbi. W ciągu tygodnia spiskowcom udało się spacyfikować cały kraj ${ }^{52}$.

Dzień 9 czerwca 1923 r. był „czarnym dniem” w historii bułgarskiego ruchu ludowego, który rozpoczął bezpośredni upadek BLZCh. Znaczący wpływ na taki stan rzeczy miała niewątpliwie brutalna eliminacja z życia politycznego działaczy Związku. Georgi Darinowa po aresztowaniu niedaleko Płowdiwu torturowano, a jego ciało wyrzucono później z jadącego pociągu. Kruma Popowa, Stojana Kałyczewa i Dimityra Kemałowa zastrzelono w celi policyjnej w Sofii. Podobny los spotkał ok. 20 innych deputowanych z ramienia Związku. Ogólnie, w wyniku przewrotu czerwcowego w latach 1923-1925 śmierć poniosło kilka tysięcy działaczy ludowych ${ }^{53}$, a porównywalna liczba osób została aresztowana lub zmuszona do emigracji. Równocześnie oficjalna działalność Związku zamarła, a pozostający w Bułgarii politycy BLZCh zmuszeni zostali do zejścia do podziemia.

Prześladowania członków i działaczy ludowych po zamachu czerwcowym spowodowały także rozdźwięki wewnątrz BLZCh i nasiliły walki frakcyjne. W miarę upływu czasu pogłębiały je działania podjęte przez kierownictwo ugrupowania na rzecz odbudowy struktur Związku, co wiązało się z koniecznością odejścia od wcześniejszej linii politycznej i zaprzestaniem walki z rządem Cankowa ${ }^{54}$. Działania prawicy Związku spotkały się ze sprzeciwem lewego skrzydła ludowców skupionego wokół pisma „Narodna zasztita”, a następnie gazety „Zemedełsko wyzrażdene”, które postulowało zacieśnienie współpracy z BPK ${ }^{55}$. Trzecią frakcję tworzyło centrum opo-

${ }^{51}$ Z. Hemmerling, op. cit., s. 327.

52 Por. J. D. Bell, op. cit., s. 238.

53 Ibidem, s. 245; zob. także: J. R. Lampe, op. cit., s. 50.

${ }^{54}$ Por. D. Tiszew, Edinodejstveto meždu komunisti i zemedelci, Sofiâ 1967, s. 111.

${ }_{55}$ Efektem podjętej współpracy był udział części ludowców w tzw. powstaniu wrześniowym, we wrześniu 1923 r., które zorganizowali komuniści dla obalenia rządu Cankowa. W kilku starciach z wojskiem 
wiadające się za kontynuowaniem polityki z okresu rządów Stambolijskiego. W tym czasie podziałom ulegały także środowiska emigracyjne, skupiające ludowców, którzy po zamachu czerwcowym opuścili Bułgarię, udając się do Francji, Czechosłowacji i Jugosławii ${ }^{56}$.

Nasilająca się walka frakcyjna doprowadziła ostatecznie z końcem 1926 r. do faktycznego rozbicia związku na dwa ugrupowania. Część działaczy sprzeciwiająca się działaniom związkowej prawicy zwołała tzw. mały kongres związkowy, który wyłonił nowe władze z Dimityrem Giczewem i Konstantinem Murawiewem na czele, a ugru-

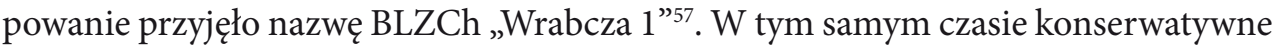
skrzydło Związku pod przewodnictwem Kosty Tomowa utworzyło organizację pod nazwą BLZCh „Oranżew”58. Podział ten potwierdził odbywający się w kwietniu $1927 \mathrm{r}$. XVIII Kongres BLZCh, który zwołany został w celu opracowania planu przygotowań do wyznaczonych na maj wyborów parlamentarnych. Do porozumienia jednak nie doszło. Tym samym oba ugrupowania przystąpiły do wyborów w różnych koalicjach: „Wrabcza 1” wspólnie z Partią Socjaldemokratyczną i Rzemieślniczą, natomiast "Oranżew” z Partią Demokratyczną i Narodowo-Liberalną. Warto także zaznaczyć, że w wyborach grupa ludowców wystartowała także z list - utworzonego z inicjatywy BPK - Bloku Pracy. Ogółem ludowcom udało się wprowadzić do Zgromadzenia 65 posłów.

Proces rozpadu BLZCh trwał jednak dalej. W lutym 1929 r. BLZCh „Wrabcza 1” podzielił się na dwa antagonistycznie nastawione do siebie nurty, które zorganizowały dwa XX Kongresy Związku. Mimo podejmowanych wysiłków nie udało się ich ze sobą pogodzić, a rozbicia ugrupowania nie zlikwidował nawet obradujący w listopadzie 1929 r. XXI Kongres, nazywany zjednoczeniowym. Trudno zatem dziwić się, że w kolejnych wyborach parlamentarnych w $1931 \mathrm{r}$. ludowcy, ponownie startujący $\mathrm{z}$ różnych list, tylko nieznacznie poprawili poprzedni wynik i wprowadzili do Zgromadzenia Narodowego 72 posłów. Równocześnie jednak wybory te stanowiły kres rządów spiskowców, którzy przejęli władzę w wyniku zamachu stanu z 1923 r. Misję tworzenia nowego gabinetu Borys III powierzył liderowi demokratów A. Malinowowi, a w jego składzie znaleźli się trzej ludowcy: K. Murawiew, D. Giczew i Georgi Jordanow, odpowiednio jako ministrowie: oświaty, rolnictwa i robót publicznych.

oddziały powstańcze zostały jednak rozbite, a powstanie upadło. Jego następstwem było wzmocnienie terroru, którego ofiarami padali zarówno komuniści, jak i ludowcy; szerzej na ten temat m.in.: P. Kostow, Septemvri 1923. W edinen front za robotničesko-selska vlast, Sofiâ 1973; zob. także: Z. Hemmerling, op. cit., s. 329-330 oraz M. Kumanow, op. cit.

56 Tłem sporu był m.in. stosunek do komunistów, a nasilił się on na początku 1924 r., kiedy Przedstawicielstwo Zagraniczne BLZCh zdecydowało się na zawarcie z BPK porozumienia w kwestii przygotowania kolejnego powstania i powołania wspólnego rządu. Część emigracyjnych działaczy nie tylko krytykowała umowę, lecz także bojkotowała jej postanowienia; szerzej na ten temat D. Petrowa, Georgi Dimitrov i BZNS 1923-1949, Sofiâ 1972, s. 17-18, 32.

${ }^{57}$ Nazwa pochodziła od ulicy w Sofii, przy której mieściła się siedziba Związku.

${ }^{58}$ Zob. M. Kumanow, op. cit. 
Pomimo trwającego osiem lat terroru i prześladowań skierowanych przeciw ludowcom oraz mimo postępującego rozpadu BLZCh ugrupowaniu udało się zachować szerokie wpływy wśród chłopstwa bułgarskiego. W zmienionej sytuacji politycznej stwarzało to możliwość szybkiej odbudowy znaczenia organizacji, a nawet pozwalało snuć plany o samodzielnym sprawowaniu władzy. Dobrą koniunkturę w tym zakresie stwarzały ludowcom konsekwencje wielkiego kryzysu gospodarczego, który pociągnął za sobą przede wszystkim dramatyczny wzrost bezrobocia i poziomu zadłużenia społeczeństwa, a także bardzo poważny spadek produkcji przemysłowej i rolniczej oraz cen na produkty bułgarskie, a co za tym idzie znaczną obniżkę eksportu i deficyt $\mathrm{w}$ wymianie handlowej ${ }^{59}$. Panujące powszechnie, a przybierające szczególnie duże rozmiary na wsi, niezadowolenie społeczne skłoniło działaczy ludowych do wysunięcia haseł walki ze skutkami kryzysu i powrotu do pozaparlamentarnych metod walki, takich jak wiece i demonstracje uliczne. Równocześnie w sferze politycznej postulowali oni zintensyfikowanie wysiłków na rzecz unifikacji organizacyjnej i ideowej Związku, co umożliwiłoby ugrupowaniu pełne odzyskanie dawnych wpływów politycznych.

Idea ta nie znalazła jednak szerszego oddźwięku, a dodatkowo ujawniły się nowe tendencje odśrodkowe, które doprowadziły do kolejnych podziałów w bułgarskim ruchu ludowym. Tłem stała się sprawa amnestii dla przebywających na emigracji działaczy. W tej kwestii rozgorzał spór między D. Giczewem a G. M. Dimitrowem, liderem utworzonej jeszcze w 1928 r. frakcji w BLZCh „Wrabcza 1”, skupionej wokół czasopisma „Pładne”. Ponieważ kwestia powrotu niektórych spośród emigrantów natrafiała na opór części sił politycznych, w tym także tych, które wspólnie z ludowcami tworzyły rząd, Giczew oświadczył, że nie będzie wszczynał sporów wokół amnestii dla 4 emigracyjnych liderów ${ }^{60}$, a ostatecznie stwierdził, że objęcie amnestią dawnych przywódców Związku może spowodować niepokoje społeczne o nieprzewidywalnych skutkach. Zdecydowanie odmienne stanowisko zajęła grupa „Pładne”. Pogłębiający się antagonizm pomiędzy oboma frakcjami prowadził do nowych sporów ${ }^{61}$, a w 1932 r. spowodował secesję G. M. Dimitrowa i popierających go polityków, którzy utworzyli nowe ugrupowanie pod nazwą BLZCh „Aleksandyr Stambolijski”" ${ }^{2}$. Pierwszy kongres tej partii odbył się w listopadzie 1932 r. w Starej Zagorze, gromadząc ponad 1200 delegatów i zaproszonych gości ${ }^{63}$. W trakcie obrad wybrano władze partii w postaci Rady Wykonawczej, do składu której powołano m.in. wszystkich czterech przebywających na emigracji liderów BLZCh, a A. Obbowowi powierzono ponadto honorową prezesurę Związku.

${ }^{59}$ Por. ibidem.

${ }^{60}$ Chodziło o zgodę na przyjazd do Bułgarii K. Todorowa, A. Obbowa, Ch. Stojanowa i N. Atanasowa.

${ }^{61}$ Ch. A. Moser, Dimitrov of Bulgaria. A Political Biography of dr. Georgi M. Dimitrov, New York 1979, s. 60 .

${ }^{62}$ W tym czasie z BLZCh „Wrabcza 1” wystąpiła także grupa pod przywództwem Georgi Markowa, która połączyła się z BLZCh „Oranżew”, tworząc nowe ugrupowanie BLZCh „Serdika”. Dwa lata później uległo ono jednak rozpadowi, a Markow i jego sympatycy powrócili do BLZCh „Wrabcza 1”.

${ }^{63}$ Ch. A. Moser, op. cit., s. 65. 
Po ich powrocie do Bułgarii wiosną 1933 r. ponownie pojawiły się wśród ludowców hasła wzywające do zjednoczenia ruchu. Ich efektem było podjęcie w końcu czerwca rozmów między działaczami BLZCh „Aleksandyr Stambolijski” i BLZCh „Wrabcza 1", których celem miało być stworzenie warunków do ponownego zjednoczenia obu odłamów. Mimo początkowych trudności do połączenia doszło zaledwie dwa miesiące później. Warto jednak dodać, że wzięła w nim udział tylko część działaczy BLZCh „Wrabcza 1”. 17 sierpnia 1933 r. podczas spotkania w Sofii reprezentanci obu ugrupowań podpisali porozumienie o powołaniu do życia partii o nazwie BLZCh "Zjednoczony" ${ }^{64}$. W skład jej Komitetu Wykonawczego weszli: G. Jordanow, C. Stojanow i N. Atanasow z „Wrabcza 1” oraz K. Todorow, A. Obbow i G. M. Dimitrow z „Aleksandyr Stambolijski”. Sekretarzem ugrupowania został Ch. Stojanow, K. Todorowowi powierzono stanowisko rzecznika prasowego, G. Jordanow odpowiadał za dział organizacyjny, a G. M. Dimitrow i Awram Awramow reprezentowali w Komitecie Wykonawczym nową grupę parlamentarną, powołaną do życia w związku z utworzeniem nowej partii. Formowanie nowego ugrupowania zakończył I Kongres BLZCh, który odbył się w Sofii 21 listopada $1933 \mathrm{r}$.

Nieskrępowana działalność nowego ugrupowania trwała jednak zaledwie kilka miesięcy. W maju 1934 r. doszło bowiem w Bułgarii do kolejnego zamachu stanu, w wyniku którego władzę przejęła organizacja pod nazwą Koło Polityczne „Zweno”, skupiająca profrancuską burżuazję o nastawieniu republikańskim i cieszącą się poparciem postępowej inteligencji oraz kół wojskowych ${ }^{65}$. Efektem tych działań było utworzenie nowego gabinetu z pułkownikiem Kimonem Georgiewem na czele. Ponieważ zwenarzy byli zdecydowanymi przeciwnikami parlamentarnej formy rządów, wrogo odnosili się także do partii i ugrupowań politycznych. Z drugiej strony, chcąc utrzymać się przy władzy i wprowadzić w życie swój program, zmuszeni byli do stosowania represji. W związku z tym rozwiązali oni Parlament i zmienili Konstytucję Tyrnowską, a następnie wprowadzili cenzurę, zakazali działalności organizacji politycznych, skonfiskowali ich mienie oraz zabronili wszelkiej agitacji politycznej i organizowania wieców i demonstracji. W tych warunkach możliwości działania Związku były bardzo utrudnione, ale nadchodzące wydarzenia miały jeszcze bardziej skomplikować sytuację.

Rządy zwenarów, wrogo odnoszące się również do dynastii Koburgów, zmobilizowały do działania Borysa III $^{66}$. Po zapewnieniu sobie poparcia Ligi Wojskowej, w styczniu 1935 r., car obalił rząd Georgiewa i powołał nowy, zupełnie mu podległy, gabinet gen. Petyra Zlatarewa. Rozbicie, jesienią tego roku, przygotowywanego przez republikanów kolejnego zamachu stanu oraz sformowanie rządu na czele z Georgi Kioseiwanowem utrwaliły ustrój autorytarny w Bułgarii i skupiły pełnię władzy w rękach cara.

${ }^{64}$ Ugrupowanie to szybko jednak uległo rozpadowi. W jego wyniku powstał BLZCh „Aleksandyr Stambolijski” oraz grupa „Selska Włast”, skupiona wokół czasopisma „Zemja i trud”.

${ }^{65} \mathrm{Na}$ ten temat szerzej: R. J. Crampton, Eastern Europe, s. 125-126; zob. także: Nacionalno-osvoboditelnoto dviženie, s. 303.

${ }^{66}$ Zob. R. J. Crampton, Eastern Europe, s. 127-128. 
Przejście ludowców od opozycji antyrządowej skłaniało liderów ruchu do intensyfikacji działań na rzecz zjednoczenia Związku. Z inicjatywą w tej kwestii wystąpił, pod koniec maja 1936 r., G. M. Dimitrow, który planował zwarcie chłopskich szeregów, co ułatwiłoby przeciwstawianie się prowadzonej przez cara polityce ${ }^{67}$. Zabiegi te nie dały jednak spodziewanych rezultatów, mimo iż opracowany plan unifikacji przewidywał stworzenie federacji różnych odłamów ruchu ludowego, w której każdy z nich miał mieć znaczną dozę samodzielności. Sugestie te spotkały się z oporem działaczy BLZCh „Wrabcza 1”, którzy uważali, że ludowcy powinni stanowić jedną siłę, ale pod ich kierownictwem ${ }^{68}$.

Równocześnie jednak aktywiści ludowi starali się uczestniczyć w różnych nurtach opozycji antyrządowej w Bułgarii. W maju 1936 r. liderzy opozycji burżuazyjnej, w tym D. Giczew, wystosowali do cara tzw. memorandum „pięciu”, w którym domagali się przywrócenia Konstytucji Tyrnowskiej i przeprowadzenia wolnych wyborów. W tym samym czasie G. M. Dimitrow nawiązał kontakt z opozycją lewicową. Brak oczekiwanych ustępstw ze strony rządu i cara skłonił oba nurty opozycyjne do podjęcia współpracy. Jej efektem było organizowanie wspólnych komitetów, walczących o przywrócenie konstytucji i praw obywatelskich. Nie przyniosło to jednak zjednoczenia ludowców, a można nawet stwierdzić, że zaostrzyło walkę o prymat w ruchu ${ }^{69}$. Przycichała ona okazjonalnie podczas ważnych wydarzeń politycznych, ale po ich zakończeniu wybuchała ponownie. Jednym $\mathrm{z}$ okresów zbliżenia ugrupowań ludowych były wybory do Zgromadzenia Narodowego w marcu 1938 r., na które rząd i car zdecydowali się pod naciskiem opozycji. Jednak przygotowana i wprowadzona w życie przez gabinet Kioseiwanowa ordynacja wyborcza ułatwiała zwycięstwo partiom prorządowym, które zdobyły 97 miejsc w Parlamencie. Pozostałe 63 mandaty podzieliła między siebie opozycja, która do wyborów przystąpiła zgrupowana w tzw. bloku konstytucyjnym.

W nowym parlamencie zaznaczyła się duża polityczna aktywność członków BLZCh „Aleksandyr Stambolijski”. Nie tylko nie ograniczali się oni do krytyki działań rządu, lecz także starali się - w miarę możliwości - wpływać na kierunki prowadzonej polityki. Wiele miejsca poświęcano zwłaszcza polityce zagranicznej, w której postulowano zerwanie z Niemcami i uzyskanie gwarancji ze strony Wielkiej Brytanii i Francji oraz podjęcie działań na rzecz stworzenia federacji państw bałkańskich opartej na sojuszu bułgarsko-jugosłowiańskim, co położyłoby kres obcej penetracji i zabezpieczyłoby państwa regionu przed agresją krajów trzecich. Propagowane przez ludowców hasła nie były dobrze postrzegane przez rząd, a zwłaszcza cara, który opowiadał się za zacieśnieniem współpracy z państwami faszystowskimi ${ }^{70}$. Zakończyło się to ostatecznie usunięciem z parlamentu pod koniec $1938 \mathrm{r}$. najbardziej niewygodnych deputowanych

${ }^{67}$ Por. W. Georgiew, Buržoaznite i drebnoburžoaznite partii w B"lgariâ 1934-1939, Sofiâ 1970, s. 224.

${ }^{68}$ Ch. A. Moser, op. cit., s. 120.

${ }^{69}$ Ibidem, s. 122.

70 Borys III widział w tym jedyną możliwość wzmocnienia międzynarodowej pozycji Bułgarii, a krytykując opozycję, często powtarzał: „Moja armia jest proniemiecka, moja żona jest Włoszką, mój 
ludowych oraz internowaniem niektórych z nich ${ }^{71}$. Głoszone przez ludowców idee oraz ich antymonarchistyczna postawa, którą przyjęli na początku 1939 r., przysporzyły im sporo sympatii zarówno w społeczeństwie, jak i w innych opozycyjnych ugrupowaniach politycznych. Niestety, nie liczyły się one w grze politycznej, co potwierdziły kolejne wybory parlamentarne przeprowadzone w styczniu $1940 \mathrm{r}$. Opozycja uzyskała w nich zaledwie 20 mandatów, z czego 5 przypadło na BLZCh „Aleksandyr Stambolijski”.

Wybuch II wojny światowej niewiele zmienił sytuację polityczną w Bułgarii, ale w miarę upływu czasu rosła liczba przeciwników autorytaryzmu Borysa III i jego najbliższych współpracowników. Równocześnie zwiększało się poparcie dla opozycji, domagającej się przywrócenia praw obywatelskich i zerwania sojuszu z III Rzeszą, do której należały także oba ugrupowania ludowe: BLZCh „Aleksandyr Stambolijski” i BLZCh „Wrabcza 1”. Jej rola rosła w miarę zbliżania się Armii Czerwonej do granic Bułgarii i - w związku z tym - klęski Niemiec. Równocześnie sytuacja państwa ulegała stopniowemu skomplikowaniu. Podstawowym problemem był wybór odpowiedniej drogi, którą Bułgaria mogłaby wyjść z wojny z relatywnie najmniejszymi stratami politycznymi i terytorialnymi. Możliwości nie było wiele. Jedną z nich było jak najszybsze rozpoczęcie rozmów z mocarstwami zachodnimi - USA i Wielką Brytanią - i poddanie się pod ich protekcję. Rząd Iwana Bagrianowa z początkiem czerwca 1944 r. podjął nawet próby w tej kwestii, lecz nie zakończyły się sukcesem. Kontynuował je jednak kolejny koalicyjny gabinet utworzony 2 września 1944 r. pod przewodnictwem ludowca - K. Murawiewa z BLZCh „Wrabcza 1”, ale ich skutek był podobny ${ }^{72}$. Drugą możliwością było podjęcie współpracy z komunistami i formowanym przez nich od 1942 r. Frontem Ojczyźnianym. Idea ta była tym łatwiejsza do realizacji, że komuniści, zdając sobie sprawę ze słabości partii i własnego ruchu partyzanckiego, sami występowali z propozycją współdziałania ${ }^{73}$. Równocześnie w Bułgarii, w związku z panującym od dwóch dziesięcioleci terrorem, partie demokratyczne były mocno osłabione i niezdolne do samodzielnego tworzenia silniejszych ośrodków politycznych. Dlatego też wielu liderów decydowało się na podjęcie współpracy w ramach Frontu Ojczyźnianego po to, aby ich „ucywilizować” lub w oparciu o nich budować własną pozycję. Dlatego też w składzie Frontu, głównie z inicjatywy Nikoły Petkowa, znalazł się ostatecznie także BLZCh „Aleksandyr Stambolijski”74.

Fiasko prowadzonych przez rząd rozmów $\mathrm{z}$ aliantami zachodnimi skłoniły kierownictwo Frontu do przejęcia władzy, zwłaszcza że pojawiła się dobra po temu koniunktura. Nastąpiło to nazajutrz po wkroczeniu Armii Czerwonej do Bułgarii. 8 września 1944 r. na posiedzeniu Krajowej Rady Frontu Ojczyźnianego ustalono

lud jest prorosyjski. Tylko ja jeden jestem probułgarski”; R. J. Crampton, Eastern Europe, s. 128; zob. także: Nacionalno-osvoboditelnoto dviženie, s. 295-298.

${ }^{71}$ M.in. Nikołę Petkową.

72 J. Jackowicz, Partie opozycyjne w Bułgarii 1944-1948, Warszawa 1997, s. 10.

${ }_{73}$ Zob. G. Gundew, K"m brega na svobodata ili za Nikoła Petkov i negovoto vreme, Sofiâ 1992, s. 51.

${ }^{74}$ Ibidem, s. 46. 
skład nowego rządu, a następnego dnia oficjalnie powołano go do życia. Skład gabinetu K. Georgiewa był wprawdzie formalnie koalicyjny ${ }^{75}$, ale zdecydowaną większość posiadali w nim komuniści z Bułgarskiej Partii Robotniczej ${ }^{76}$. Po uzyskaniu kontroli nad kluczowymi resortami przystąpili oni do budowy nowego systemu państwowego, wzorowanego na systemie radzieckim. Działania te spotkały się z krytyką innych ugrupowań politycznych skupionych we Froncie Ojczyźnianym. Ich liderzy stanęli na stanowisku, że główne cele, które sobie wyznaczyli, przystępując do Frontu, zostały osiągnięte i sprzeciwiali się dalszym przemianom mającym stworzyć i ugruntować w Bułgarii system totalitarny. Szczególne zaniepokojenie budził w nich fakt, że najważniejsze decyzje coraz częściej zapadały poza rządem, a nawet poza Radą Frontu Ojczyźnianego. Prowadziło to do poważnych napięć, a szczególnie zacięty spór toczył się wokół kompetencji Ministerstwa Spraw Wewnętrznych, kontrolowanego przez BPR (k) i Ministerstwa Wojny ${ }^{77}$, kierowanego przez zwenara, Damiana Wełczewa, którego tłem były czystki przeprowadzane w szeregach armii przez organy bezpieczeństwa ${ }^{78}$. Mimo kilkakrotnie podejmowanych prób zażegnania konfliktu nie udawało się go załagodzić przez dłuższy czas i zakończył się on dopiero w połowie grudnia $1944 \mathrm{r}$.

Próby ugruntowania przez komunistów silnej pozycji dotyczyły nie tylko armii. Dużą uwagę przywiązywali także do „oczyszczenia” sceny politycznej poprzez eliminowanie lub przynajmniej poważne osłabienie przeciwników politycznych w partiach ${ }^{79}$. Szczególnie dotyczyło to BLZCh, którego kierownictwo nie zamierzało poddać się naciskom i wkrótce stało się filarem antykomunistycznej opozycji w Bułgarii. Szczególny wpływ na taki stan rzeczy miał powrót do kraju 23 września 1944 r. oficjalnego przewodniczącego BLZCh „Aleksandyr Stambolijski” - G. M. Dimitrowa ${ }^{80}$, przebywającego od 1941 r. na emigracji. Świadomy popularności Związku wśród chłopów, niemal natychmiast rozpoczął szeroką krytykę działań komunistów, a szczególnie sprzeciwiał się panującemu w kraju terrorowi i łamaniu praw obywatelskich. Wykorzystywał on przy tym fakt, że BPR (k) nie mogła pozwolić sobie na zerwanie z ludowcami i pozbawienie Frontu Ojczyźnianego kontroli nad wsią. Równocześnie G. M. Dimitrow rozpoczął działania na rzecz odbudowy struktur Związku ${ }^{81}$. Z jego inicjatywy zwołany został, pierwszy od 1933 r., kongres BLZCh, który odbył się w dniach 14-15 października 1944 r. w Sofii. Podczas obrad potwierdzono jego przywództwo w partii, wybierając go na stanowisko sekretarza generalnego, powołano do życia Centralny Komitet, w skład którego weszli: N. Petkow, Asen Pawłow, Boris Bumbarow i kilku innych oraz podjęto decyzję o rozbudowie struktur ugrupowania.

75 Znalazł się w nim m.in. N. Petkow jako minister bez teki i trzech innych ludowców.

${ }^{76}$ Bułgarska Partia Robotnicza została utworzona w 1931 r. z połączenia BPK i działającej od 1927 r.

Partii Robotniczej.

77 Spór ten szczegółowo omawia: J. Jackowicz, op. cit., s. 15-19.

${ }^{78} \mathrm{Na}$ ten temat zob. Ż. Cwerkow, S"d"t nad opozicionnite lideri, Sofiâ 1991, s. 13.

79 Zob. J. Jackowicz, op. cit., s. 16.

${ }^{80}$ G. Gunew, op. cit., s. 60.

${ }^{81}$ Szerzej zob. Ch. A. Moser, op. cit., s. 254 i n. 
Jeszcze w listopadzie 1944 r. na terenie całego kraju przeprowadzono wiele spotkań, na których zachęcano do jedności związkowej i partyjnej. Efektem szybkiego rozwoju organizacyjnego były: drugi kongres BLZCh ${ }^{82}$ (10 grudnia) oraz wielka manifestacja ludowców (24 grudnia) w Płowdiwie.

Niezwykła popularność G. M. Dimitrowa oraz jego bezkompromisowa postawa wobec poczynań komunistów skłoniły tych ostatnich do przeciwdziałania ${ }^{83}$ prowadzonego dwutorowo. Z jednej strony, zdecydowano się faworyzować pozostający poza Frontem Ojczyźnianym i posiadający marginalne poparcie BLZCh „Wrabcza 1” oraz rozpocząć propagandę przeciw BLZCh „Aleksandyr Stambolijski”, z drugiej strony, zamierzano doprowadzić do zmiany przewodniczącego Związku. Dimitrowa miał zastąpić N. Petkow, którego komuniści uznawali za polityka chwiejnego i ustępliwego ${ }^{84}$. Ten jednak nie był początkowo zainteresowany tą propozycją ${ }^{85}$. W tej sytuacji, G. M. Dimitrow wielokrotnie zapewniał o swojej lojalności wobec Frontu Ojczyźnianego i idei sojuszu robotniczo-chłopskiego, ale nie zmieniło to jednak sytuacji. Poza tym w kampanii przeciw niemu komuniści zaczęli wykorzystywać oficerów radzieckich przebywających w Bułgarii w ramach Sojuszniczej Komisji Kontrolnej ${ }^{86}$. Od tego momentu naciski na BLZCh „Aleksandyr Stambolijski” przybrały na sile, a komuniści nie cofali się nawet przed demonstracją siły. Jedna z nich miała miejsce podczas obrad Prezydium i Najwyższej Rady Związkowej BLZCh, które odbywały się w dniach 18-20 stycznia 1945 r. Budynek Wydziału Agronomii Uniwersytetu Sofijskiego został otoczony przez jednostki Armii Czerwonej i bułgarskie służby bezpieczeństwa, a na wprost wejścia ustawiono czołg ${ }^{87}$. Dla zgromadzonych ludowców stało się jasne, że albo Związek przestanie istnieć jako ugrupowanie polityczne, albo G. M. Dimitrow przestanie być sekretarzem generalnym. $\mathrm{Z}$ tego faktu zdawał sobie sprawę także sam Dimitrow. W trakcie obrad wygłosił on przemówienie, a następnie podał się do dymisji. Jego następcą wybrano N. Petkowa.

Zmiana przywódcy BLZCh „Aleksandyr Stambolijski”, tak pożądana przez komunistów, nie rozwiązała ich problemów. N. Petkow okazał się bowiem, wbrew oczekiwaniom, twardym politykiem i aż do $1947 \mathrm{r}$. bronił niezależności Związku, uniemożliwiając jego podporządkowanie BPR (k). Równocześnie przez ponad dwa lata skupiał wokół siebie opozycję demokratyczną, blokując wprowadzenie systemu totalitarnego w Bułgarii.

People's movemet in Bulgaria in the years 1914-1944

The years 1914-1944 are an extremely uneasy period in the history of Bulgaria, not only in the national context, but also on a international scale. It was a time of two massive military conflicts which swept across Europe and inevitably involved Bulgaria. It was also a time of several political crises and coup d'etats.

82 Ibidem, s. 193.

83 Szerzej na ten temat: ibidem, s. 197 i n.

${ }^{84}$ Por. G. Gunew, op. cit., s. 61.

${ }^{85}$ Ibidem, s. 62.

86 Zob. J. Jackowicz, op. cit., s. 33.

${ }^{87}$ G. Gunew, op. cit., s. 66. 
The history of Bulgarian people's movement was strictly connected with those significant events. That was because BLZCh, fairly popular in the countryside, was one of leading political parties in Bulgaria. Powerful background, constituted by Bulgarian peasants, allowed the Union to consider itself the leader of the opposition and take over the power over the country in 1919-1920. The people's rule, however, faced strong resistance from right-wing political groups, and ended in a coup d'etat in 1923.

The period that followed was undoubtedly one of the hardest in the history of the Union. Not only was the people's movement (BLZCh) forced to go into the Underground, but also went through serious conflicts inside itself, which eventually led to its breakup. Bulgarian peasantry activists returned to the political scene only at the beginning of the 1930s, but competing fractions of the movement no longer played as important a role as they had previously.

Changes that followed the end of World War II allowed people's movement activists to become the centre of attention again. The movement, traditionally supported by the peasantry, became a pillar of the opposition against communists who were trying to impose a totalitarian system in Bulgaria. However, in the transformed geopolitical situation, it was not able to lead an equal fight and eventually left the historical scene in 1947.

Народное движение в Болгарии в 1914-1944гг.

1914-1944 гг.- это необычайно бурное время в истории Болгарии, связанный не только с ее внутренней, но также и международной политикой. Это был период не только двух крупных вооруженных конфликтов, которые охватили всю Европу и втянули Болгарию в свой водоворот, но также время политических кризисов и государственных переворотов. С этими важными событиями тесно была связана история болгарского народного движения. Происходило так потому, что пользующийся огромной популярностью в деревне Болгарский Земледельческий Народный Союз (БЗНС), был одной из главных политических партий в Болгарии. Колоссальная поддержка, которую оказывало болгарское крестьянство, позволяла Союзу быть лидером оппозиционных партий в 1914-1918 гг. и даже находится у власти в стране в 1919-1920 гг. Правление народников встретило, однако, упорное сопротивление правых и закончилось государственным переворотом в 1923 г. Период, который наступил непосредственно после июньского переворота, был, несомненно, одним из самых трудных в истории Союза. БЗНС был загнан не только в подполье, но также переживал в это время серьезные внутренние трения, которые привели к его развалу. Только в нач. 30-х гг. XX вв. народники вернулись на болгарскую политическую сцену, но, соперничавшие между собой фракции этой группировки, не отыгрывали уже такую значительную роль как ранее. Однако динамически развивающие в Болгарии события, связанные с окончанием Второй мировой войны и предпринятые коммунистами попытки введения в стране тоталитарной системы, в очередной раз поставили БЗНС в центр внимания. Пользующийся традиционной поддержкой деревни Союз стал одним из главных объединений болгарской демократической оппозиции. В изменившейся геополитической ситуации он не был в состоянии проводить равносильную борьбу и, в конце концов, в 1947 г сошел с политической сцены. 